Hydrology and Earth System Sciences, 5(3), 451-458 (2001) (C) EGS

\title{
Land use influences on acidification and recovery of freshwaters in Galloway, south-west Scotland
}

\author{
R.C. Helliwell ${ }^{1,}$ R.C. Ferrier ${ }^{1}$, L. Johnston ${ }^{1}, J_{\text {. Goodwin }}^{2}$ and R. Doughty ${ }^{2}$ \\ ${ }^{1}$ Macaulay Institute, Craigiebuckler, Aberdeen, AB15 8QH, UK \\ ${ }^{2}$ SEPA WEST, 5 Redwood Crescent, Peel Park, East Kilbride, G74 5PP, UK
}

Email for corresponding author: r.helliwell@macaulay.ac.uk

\begin{abstract}
The long term response of surface waters to changes in sulphur deposition and afforestation is investigated for three upland river systems in the Galloway region of south-west Scotland. From 1984-1999, these rivers exhibited a statistically significant decline in non-marine sulphate concentrations in response to reduced acid deposition. This reduction in non-marine sulphate was, however, insufficient to induce a $\mathrm{pH}$ recovery over the period. A statistically significant increase in river $\mathrm{pH}$ was observed between 1956-1970 $\left(0.05 \mathrm{yr}^{-1}\right)$ when subsidised agricultural lime payments were at a maximum. In 1976, this subsidy ceased and surface waters have progressively acidified. In addition, climatic change is found to influence long-term trends in $\mathrm{pH}$. Mean annual $\mathrm{pH}$ was greatest during a dry period between 1969-1973 when total annual discharge was low. Thereafter, $\mathrm{pH}$ declined gradually in response to higher rainfall and increased total annual discharge. Overall, surface waters draining the afforested catchments of the Rivers Cree and Bladnoch are more acid than those draining the moorland catchment of the Luce. These results indicate that in afforested catchments, current reductions in sulphur emissions have not led to an observed improvement in the acid status of surface waters. Forestry, therefore, represents a confounding factor with regard to chemical recovery from acidification in this region.
\end{abstract}

Keywords: acidification, afforestation, deposition, rivers, lochs, non-marine sulphate, $\mathrm{pH}$

\section{Introduction}

Historically, acid deposition has resulted in ecological damage and poor surface water quality in some of the most natural and least disturbed sites in the UK (Battarbee and Charles, 1994). Emissions of acidifying compounds to the atmosphere increased steadily from the beginning of the industrial revolution and peaked in the late 1970s (RGAR, 1997). Recently, with the adoption of stringent protocols that aim to curtail emissions of oxidised sulphur $\left(\mathrm{SO}_{\mathrm{x}}\right)$, oxidised nitrogen $\left(\mathrm{NO}_{\mathrm{x}}\right)$ and reduced nitrogen $\left(\mathrm{NH}_{\mathrm{y}}\right)$, levels of acid deposition have generally declined (Jenkins et al., 1998). Monitoring the response of surface water chemistry to costly emission reduction programmes is important, as such strategies are partly based on the assumption that improvements in water quality will result (Soulsby et al., 1995). Recent evidence on the reversibility of surface water acidification in acid sensitive areas in Europe is ambiguous: some areas have shown improvement in water quality (Evans and Jenkins, 2000; Tipping et al., 1998; Harriman et al., 1995 ) whilst other areas show little or no change (Alewell et al., 2001). The degree of reversibility is related to regional differences in deposition inputs, catchment physicochemical characteristics and land use change. In particular, land use change has been recognised as a major confounding factor in terms of restoring surface waters to good ecological/ chemical status. A considerable amount of work has been carried out to identify the effects of conifer plantations on surface water acidification over the last two decades. Much of this work in the UK has been undertaken in Galloway, a region where large-scale afforestation, high levels of deposition and predominantly acid sensitive soils and geology contribute to a highly acid sensitive environment (Wright et al., 1994; Rees and Ribbens, 1995; Lees, 1995; Puhr et al., 2000). Increased acidity of soils and surface waters in forested catchments has been associated with enhanced levels of dry and occult deposition captured by 
forest stands, alterations in soil hydrology and direct physical disturbance of the soil structure during ploughing prior to planting (Miller, 1985). It is well documented that young trees have a high demand on the soil base cation pool and this process can also enhance surface water acidification (Reynolds et al., 1994; Miller, 1985). Long term modelling studies of afforestation impacts on soil and stream acidification confirm this view (Jenkins et al., 1990a). Forest dynamics, therefore, play an important role in the acidification/recovery of surface waters.

In the present study, long-term hydrochemical analyses from the upper reaches of three rivers, the Cree, Bladnoch and Luce, are discussed. The response of surface waters to changes in sulphur ( $\mathrm{S}$ ) deposition and land use is investigated.

\section{Study area and methods}

\section{GENERAL REGIONAL DESCRIPTION}

The Galloway region of south-western Scotland is an acid sensitive environment. The highly siliceous granitic bedrock covered by thin, patchy, organic rich and generally acidic soils, offers only limited ability to neutralise acid inputs from the atmosphere (Wright et al., 1994). This region receives an annual average rainfall exceeding $2000 \mathrm{~mm}$. Bedrock

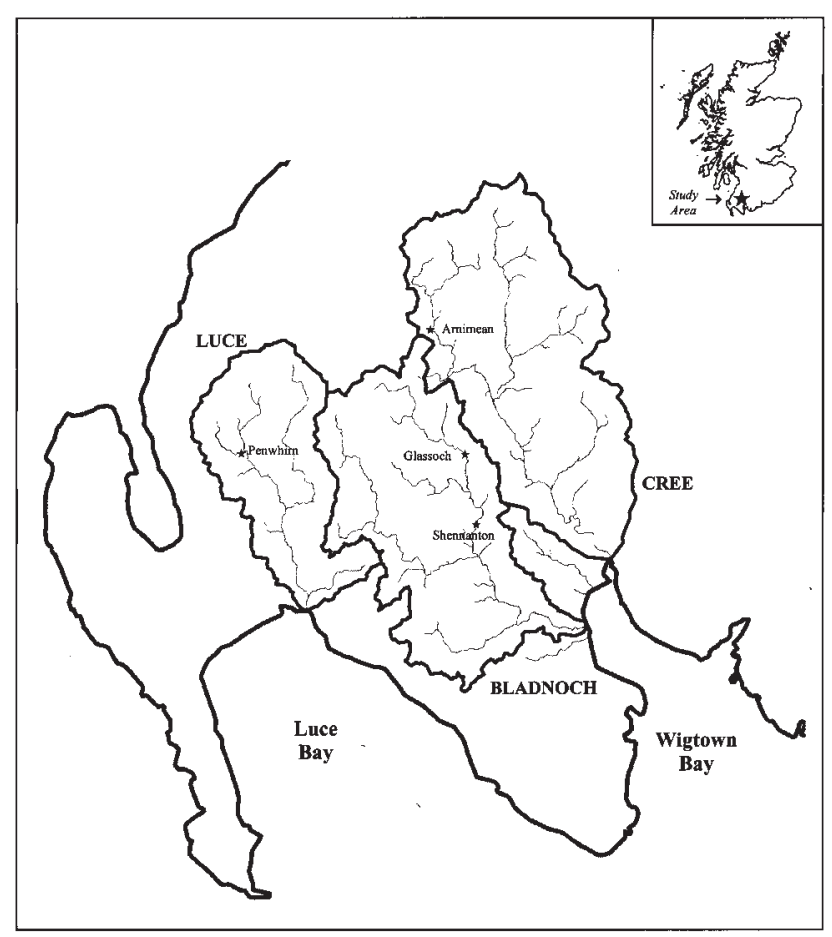

Fig. 1. Map showing the River Cree, Bladnoch, and Luce catchment boundaries and sample sites geology is characterised by Paleozoic (mainly Silurian) sedimentary rocks (shale, slate, greywacke, sandstone and conglomerate) into which granitic plutons are intruded (Daysh, 1974). These geological formations have a low capacity to buffer external acid inputs and, as a consequence, the soils are naturally acid (Edmunds and Kinniburgh, 1986).

Although small areas of rough and improved grassland occur to the south and west of the region, a considerable part of this region is covered with coniferous forest. Largescale commercial afforestation increased dramatically during the mid $20^{\text {th }}$ century with the total area of conifer woodland under Forestry Commission ownership increasing from c.6581 ha in 1940-1950 to $c .93842$ ha in 1971-80 (Forestry Commission, 1999). The total area of forest (including woodland owned by or leased to the Forestry Commission and forest under private ownership) is $170848 \mathrm{ha}$, this represents $27 \%$ of the land area in this region. Afforestation has been almost exclusively with non-native conifers such as Sitka spruce (Picea sitchensis) and lodgepole pine (Pinus contorta).

\section{DESCRIPTION OF THE RIVER CREE, BLADNOCH AND LUCE SUB-CATCHMENTS}

Soil and land use information for the sub-catchments included in this study were extracted from the digital soil map of Scotland (1:250,000) and the Land Cover of Scotland 1988. Collectively, the Rivers Luce, Cree and Bladnoch drain an area of $1102 \mathrm{~km}^{2}$ from the Galloway uplands to the Solway Firth (Fig. 1). The drainage areas of the head-water rivers included in this analysis are $62 \mathrm{~km}^{2}$ (Cree at Arnimean), $54 \mathrm{~km}^{2}$ (Bladnoch at Glassoch) and $32 \mathrm{~km}^{2}$ (Luce at Penwhirn). The Cree and Bladnoch sub-catchments are dominated by coniferous plantations $(80 \%$ and $71 \%$, respectively), the remaining area is comprised of rough grassland and heather moorland (Fig. 2a). These subcatchments were afforested during the 1950s, 60s and 70s. Since the 1980s, more forest has been planted although there is now significant felling as much of the first plantings reach maturity (Forestry Commission, 1999). The soils in the Cree and Bladnoch sub-catchments are mineral in nature and derived from greywackes and shales (Ettrick association) (Fig. 2b), although, 7\% of the Cree sub-catchment is composed of soils derived from granite (Dalbeattie association). Reference is also made to longer-term historical datasets from Shennanton, a sampling site down river from Glassoch (River Bladnoch). A large part of the Shennanton sub-catchment comprises coniferous forest $(60 \%)$ and rough grassland (23\%). Peat, brown forest soil and peaty podzols derived from greywackes and shales are the major soils types in the Bladnoch catchment. In contrast, the Penwhirn sub- 
a)

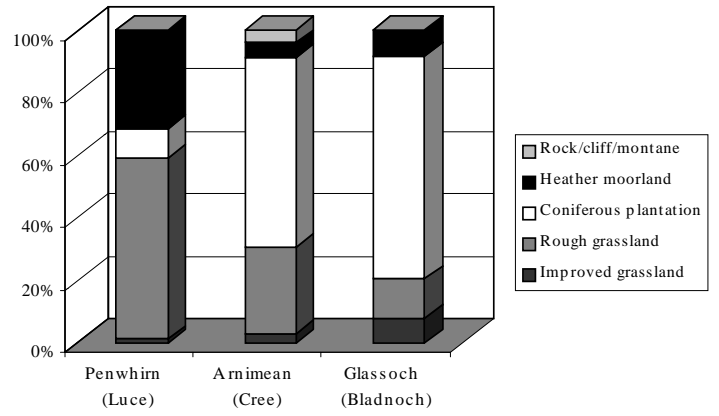

b)
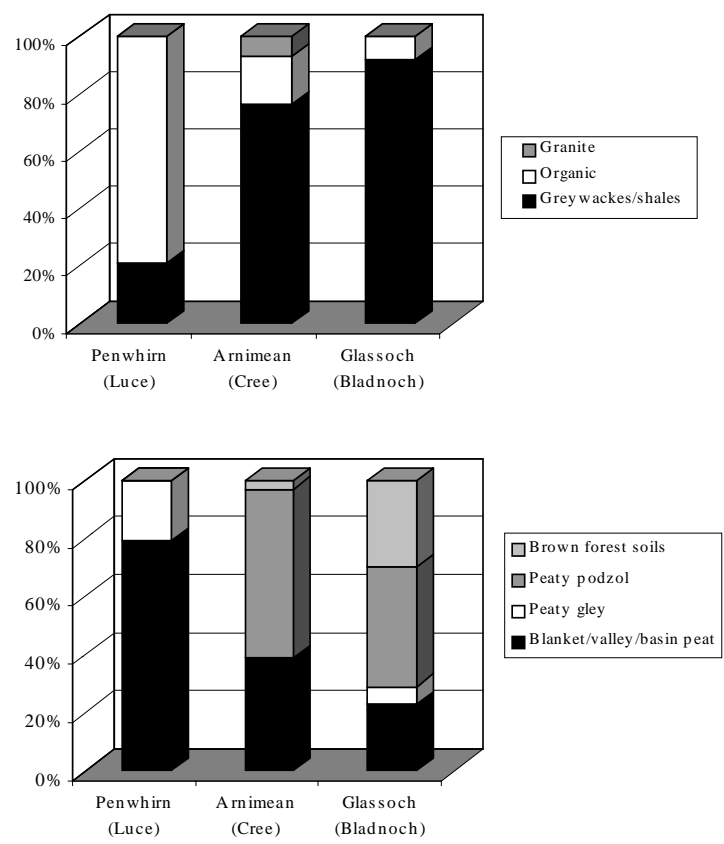

Fig. 2. Proportion of: (a) vegetation classes, (b) geology, and (c) soil types in the River Cree, Bladnoch and Luce sub-catchments.

catchment is dominated by blanket peat (80\%), with a small area of peaty gleyed soil derived from greywackes and shales (Ettrick association) surrounding the lower river channel (Fig. 2b and c). A large area of the catchment comprises rough grassland and heather moorland (89\%), only $9 \%$ of the Penwhirn sub-catchment is afforested (Fig. 2a).

Long-term monitoring data for analysis of temporal trends were obtained from the Scottish Environment Protection Agency (SEPA West region). A sampling programme was established in 1955 on the River Cree at Arnimean and the River Bladnoch at Shennanton. These sites were sampled at six-weekly intervals. This sampling programme was reviewed in 1963 to provide increased coverage of the main river tributaries on the River Cree and the sampling frequency was increased to monthly intervals. In 1980, samples were collected on a monthly to quarterly basis. It was during this year that sampling of the River Bladnoch began at Glassoch. Records of chloride $(\mathrm{Cl})$, nitrate $\left(\mathrm{NO}_{3}\right)$, gran alkalinity and $\mathrm{pH}$ began in 1956, whilst total aluminium
Table 1. Mean annual chemistry from Rivers Cree, Bladnoch, and Luce (1984-1999). All values in $\mu$ eq $\mathrm{l}^{-1}$ except $\mathrm{pH}$.

\begin{tabular}{lcccccc}
\hline & $\mathrm{pH}$ & $\mathrm{SO}_{4}$ & $\mathrm{SO}_{4}^{*}$ & $\mathrm{NO}_{3}$ & $\mathrm{Cl}$ & Alkalinity \\
\hline $\begin{array}{l}\text { Cree at } \\
\text { Arnimean }\end{array}$ & 5.4 & 104 & 69 & 8 & 336 & 88 \\
$\begin{array}{c}\text { Bladnoch at } \\
\text { Glassoch }\end{array}$ & 5.7 & 115 & 76 & 12 & 384 & 132 \\
$\begin{array}{c}\text { Luce at } \\
\text { Penwhirn }\end{array}$ & 6.0 & 94 & 54 & 3 & 340 & 259 \\
\hline
\end{tabular}

(Al) and sulphate $\left(\mathrm{SO}_{4}\right)$ were not included in routine analysis until 1984. Base cation data are very irregular in terms of the length of the records and completeness. Analysis was conducted using standard procedures adopted by SEPA (HMSO, 1980). Flow on the River Cree was recorded at Newton Stewart (NS 412 653).

A comparison of mean annual (1984-1999) surface water $\mathrm{pH}$ (derived from mean $\mathrm{H}$ concentration, Table 1) shows that samples collected from the River Cree ( $\mathrm{pH}$ 5.4) and the River Bladnoch ( $\mathrm{pH}$ 5.7) are more acid than the River Luce (pH 6.0). Alkalinity measurements replicate this pattern with the lowest mean data recorded at the River Cree $\left(88 \mu \mathrm{eq} \mathrm{l}^{-1}\right)$, and the highest at the least acid site, the River Luce $\left(259 \mu_{\text {eq }}{ }^{-1}\right)$.

The non-marine component of $\mathrm{SO}_{4}\left(\mathrm{SO}_{4}{ }^{*}\right)$ was determined by:

$$
\mathrm{SO}_{4} *=\mathrm{SO}_{4}-(\mathrm{R} * \mathrm{Cl})
$$

where $R$ is the ratio of that ion to $C l$ in seawater $(0.104$ for $\mathrm{SO}_{4}$ where concentrations are in $\mu$ eq $\mathrm{l}^{-1}$ ). The highest mean annual concentrations of $\mathrm{SO}_{4} *$ and $\mathrm{NO}_{3}$ for 1984-1999 were recorded for the River Bladnoch $\left(76 \mu \mathrm{eq} \mathrm{l}^{-1}\right.$ and $12 \mu \mathrm{eq} \mathrm{l}^{-1}$, respectively). Non-marine $\mathrm{SO}_{4}$ concentrations measured at the River Luce were slightly lower than the concentrations in the Cree and Bladnoch, with a mean concentration of $54 \mu_{\text {eq }} \mathrm{l}^{-1}$ for 1984-1999. Surface water Cl concentrations are high, and range from $336 \mu \mathrm{eq} \mathrm{l}^{-1}$ at the River Cree to $384 \mu \mathrm{eq} 1^{-1}$ at the River Bladnoch, reflecting the close proximity of these river systems to the coast.

\section{Statistical analysis}

A multiple regression model was fitted to the data (ElShaarawi et al., 1983):

$$
y_{i}=\alpha+\beta_{1} \frac{t_{i}}{365}+\beta_{2} \sin \left(2 \pi \frac{t_{i}}{365}\right)+\beta_{3} \cos \left(2 \pi \frac{t_{i}}{365}\right)+\varepsilon_{i}
$$


where $y$ is the response variable and $t$ is the date expressed as the number of days from the start of the study. This model involves an annual cycle and a linear trend. A test was carried out to determine whether the trend $b_{1}$ is significantly different from zero.

This parametric method was chosen because fitting a smooth seasonal component is more realistic than treating seasons as blocks. In addition, unequal spacing between observations does not present a problem as the day of observation is incorporated directly into the model. A similar approach was used by El-Shaarawi et al. (1983). A simple linear regression model was used to test the relationship between selected chemical determinands included in this study.

\section{Results: Trend analysis}

\section{DEPOSITION CHEMISTRY}

A long-term perspective of wet deposition was obtained from a collector at Eskdalemuir, south-west Scotland (NT 234 028). The data presented in Ferrier et al. (2001) show a non-uniform decrease in $\mathrm{SO}_{4}^{*}$ with relatively high concentrations recorded in the late 1970 s, followed by a sharp decline from $52 \mu$ eq $\mathrm{I}^{-1}$ to $29 \mu \mathrm{eq}^{1^{-1}}$ between 1980 1987. Mean annual decline in $\mathrm{SO}_{4}^{*}$ for the entire deposition record at Eskdalemuir (1973-1995) is $2.1 \mu \mathrm{eq} \mathrm{l}^{-1} \mathrm{yr}^{-1}$. The total decline in $\mathrm{SO}_{4} *$ in 1984-1995 was $18 \%$. Concentrations of calcium (Ca), magnesium ( $\mathrm{Mg}), \mathrm{NO}_{3}$ and ammonium $\left(\mathrm{NH}_{4}\right)$ in wet deposition at Eskdalemuir have remained approximately constant from the early 1980s to 1998 .

\section{COMPARISON OF HYDROCHEMICAL TRENDS FROM THE RIVERS CREE, BLADNOCH AND LUCE}

Results from the regression analysis for linear trend and annual cycle representing 1984-1999 are shown in Table 2.

\section{River Cree at Arnimean}

Significant trends were observed in the River Cree for $\mathrm{SO}_{4}$, $\mathrm{SO}_{4}^{*}, \mathrm{Cl}$, and $\mathrm{Al}$ (Table 2). At this site there has been a pronounced and highly significant decline in $\mathrm{SO}_{4}{ }^{*}$ of an estimated $20 \mu \mathrm{eq} \mathrm{l}^{-1}$ over the reported 15 years $\left(-1.34 \mu \mathrm{eq} \mathrm{l}^{-1} \mathrm{yr}^{-1}\right)$. This is in accordance with observed decreases in total deposition of S. As expected, a decline in total $\mathrm{Al}$ was observed with the decline in $\mathrm{SO}_{4} *$. In this instance the decline in surface water $\mathrm{SO}_{4} *$ is associated with a decline in base cations and $\mathrm{Al}$ appears to have decreased rather than $\mathrm{H}$. In this regard changes in deposition were sufficient to result in a general improvement in water
Table 2. Annual trends in water chemistry based on linear analysis incorporating a seasonal cycle (1984-1999). All trend estimates in $\mu \mathrm{eql}^{-1} \mathrm{yr}^{-1}$ except $\mathrm{pH}\left(\mathrm{pH} \mathrm{yr}{ }^{-1}\right)$. Total $\mathrm{Al}$ $\left(\mu \mathrm{M} \mathrm{yr}^{-1}\right) . *, * *$ and $* * *$ denotes trends significant at 0.05 , $0.01,0.001$ levels, respectively.

\begin{tabular}{lcll}
\hline & $\begin{array}{l}\text { River Cree } \\
\text { at } \\
\text { Arnimean }\end{array}$ & $\begin{array}{l}\text { River } \\
\text { Bladnoch } \\
\text { at Glassoch }\end{array}$ & $\begin{array}{l}\text { River Luce } \\
\text { at }\end{array}$ \\
& & & \\
\hline $\mathrm{pH}$ & -0.00 & -0.01 & 0.01 \\
$\mathrm{Na}$ & 0.31 & -1.30 & 2.67 \\
$\mathrm{~K}$ & 0.17 [No data] & -0.16 \\
$\mathrm{SO}_{4}$ & $-4.11^{* * *}$ & $-3.08^{* *}$ & -0.98 \\
$\mathrm{SO}_{4}^{*}$ & $-1.34 * * *$ & $-2.32^{* *}$ & -0.02 \\
$\mathrm{NO}_{3}$ & -0.19 & -0.32 & 0.18 \\
$\mathrm{Cl}^{*}$ & $-4.51^{* *}$ & -6.10 & -3.12 \\
$\mathrm{Total} \mathrm{Al}_{\mathrm{Alkalinity}}$ & $-0.09^{* * *}$ & $-7.94 * * *$ & $-11.63^{* *}$ \\
& No data & $18.62^{* *}$ & $18.86^{*}$ \\
\hline
\end{tabular}

chemistry but not for $\mathrm{pH}$ improvement. This may be due in part to continued afforestation in this area (Fig. 3) and possibly an increase in organic acids associated with rising Dissolve Organic Carbon (DOC). There are, however, no observational data available, but similar trends have been identified in the Galloway region (Harriman et al., 2001).

\section{River Bladnoch at Glassoch}

Surface water trends observed in the River Bladnoch are similar to those in the River Cree, where $\mathrm{SO}_{4}$ $\left(-3.08 \mu\right.$ eq $\left.l^{-1} \mathrm{yr}^{-1}\right)$ and $\mathrm{SO}_{4} *\left(-2.32 \mu\right.$ eq $\left.\mathrm{l}^{-1} \mathrm{yr}^{-1}\right)$ have decreased significantly throughout the record. Of the three head water tributaries, the River Bladnoch exhibits the strongest declining trend in $\mathrm{SO}_{4}^{*}$, an estimated overall decrease of $35 \mu \mathrm{eq} \mathrm{l}^{-1}$ since 1984. In addition, the statistically

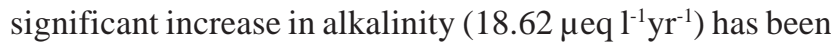
accompanied by a significant decrease in $\mathrm{Al}$ of $119 \mu \mathrm{M} \mathrm{l}^{-1}$ over 15 years $\left(-7.94 \mu \mathrm{M} \mathrm{l}^{-1} \mathrm{yr}^{-1}\right)$. This result should be interpreted with caution, particularly as the alkalinity dataset is limited to 12 data points distributed throughout the reporting period. In contrast to trends identified in the Rivers Cree and Luce (which have lower concentrations of $\mathrm{NO}_{3}$ ), a seasonal $\mathrm{NO}_{3}$ cycle can be identified in the River Bladnoch data where samples collected during the winter months have higher concentrations of $\mathrm{NO}_{3}$ compared to summer. Nonetheless, the long-term $\mathrm{NO}_{3}$ trend is not statistically significant $\left(-0.32 \mu \mathrm{eq}^{1^{-1}} \mathrm{yr}^{-1}\right)$. Rather unexpectedly, a small and statistically insignificant decline in $\mathrm{pH}$ was observed between $1984-1999\left(-0.01 \mathrm{yr}^{-1}\right)$, this trend was also evident 


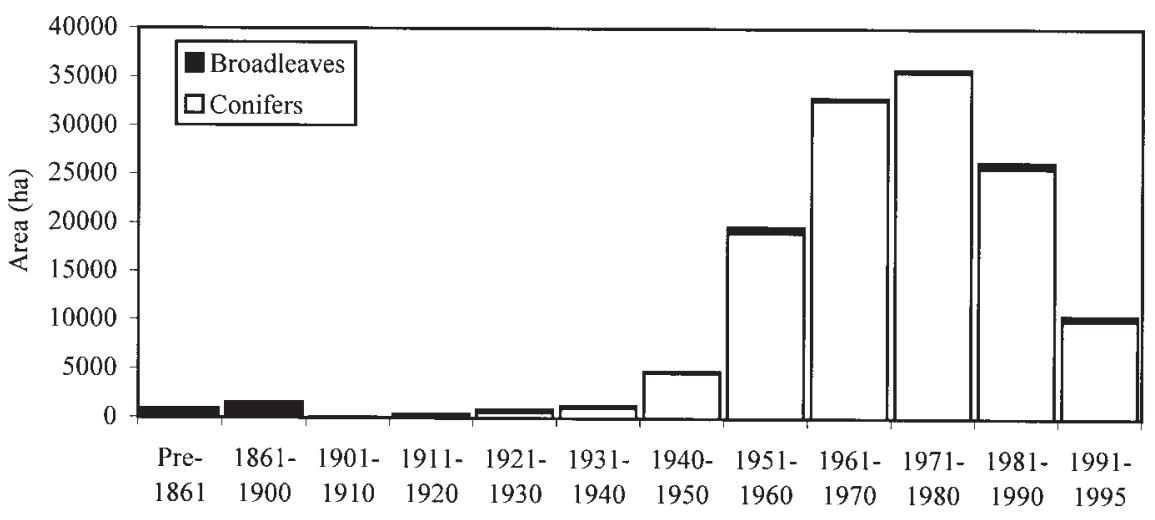

Fig. 3. Area of broadleaves and conifers in the Galloway region by planting year class

(Source: Forestry Commission, 1999)

during the same period in the River Cree. Insufficient hydrochemical data from these sites make further interpretation difficult, however, this trend should not be dismissed.

\section{River Luce at Penwhirn}

Trend analysis from the River Luce reveals very different results to those observed in the Rivers Cree and Bladnoch. Regression analysis shows a slight improvement in surface water $\mathrm{pH}$ but this is not statistically significant $\left(0.007 \mathrm{yr}^{-1}\right)$. The clear decline in total S deposition (Ferrier et al., 2001) has resulted in a small decrease in stream concentrations of $\mathrm{SO}_{4}{ }^{*}$, but this decline is not significant at the $5 \%$ level (Table 2). Compared with the afforested sub-catchments of the Rivers Cree and Bladnoch, the magnitude of the response to reduced deposition inputs is considerably smaller. Total Al has clearly declined over the 15 year period $\left(-11.63 \mu \mathrm{M} \mathrm{l}^{-1} \mathrm{yr}^{-1}\right)$ and, as a consequence, a significant increase in the alkalinity trend is observed $(18.86 \mu \mathrm{eq}$ $\left.1^{-1} \mathrm{yr}^{-1}\right)$. An inverse and highly significant relationship is observed between total $\mathrm{Al}$ and alkalinity $\left(\mathrm{r}^{2}=0.69 * *\right.$, $y=-0.5625 x+311.29)$ throughout 1984-1999.

\section{LONGER TERM TRENDS IN SURFACE WATER PH}

Historical records of surface water $\mathrm{pH}$ are limited to two sites in this study: records began in 1956 for the River Cree at Arnimean and in 1964 for the River Bladnoch at Shennanton. These data reveal very different trends in surface water acidity compared with the shorter record (1984-1999) described previously (Fig. 4). Calcium, Al, and $\mathrm{SO}_{4}$ were not included in routine analysis until the mid 1980s and in this regard, the long-term analysis is restricted to surface water $\mathrm{pH}$.

Through detailed analysis of surface water chemistry from

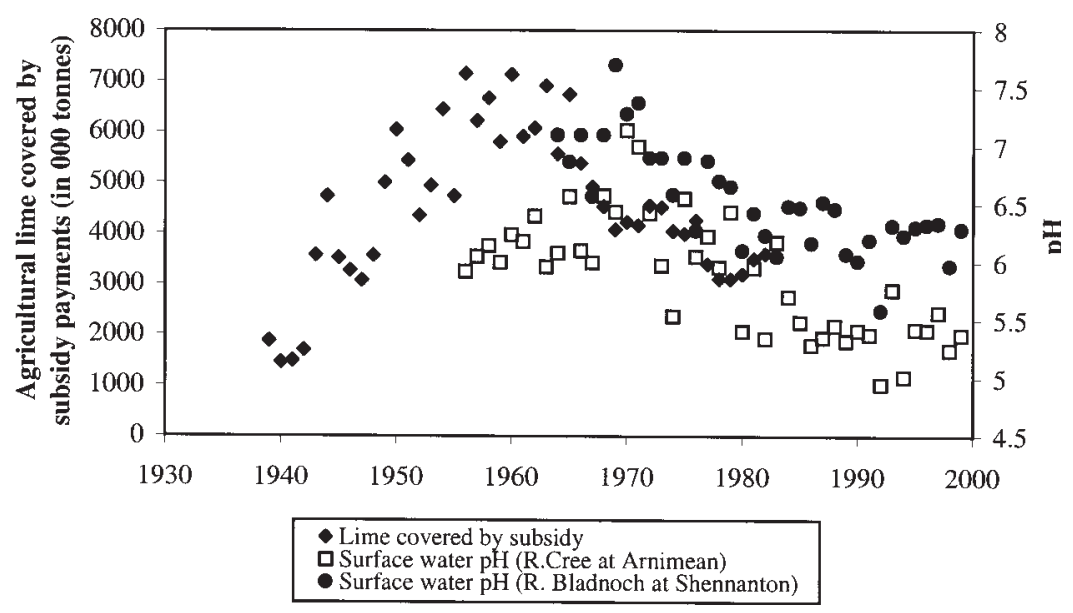

Fig. 4. UK agricultural lime use and river $\mathrm{pH}$ from the Cree at Arnimean and Bladnoch at Shennanton (Source of subsidy information: BACMI (1983)) 


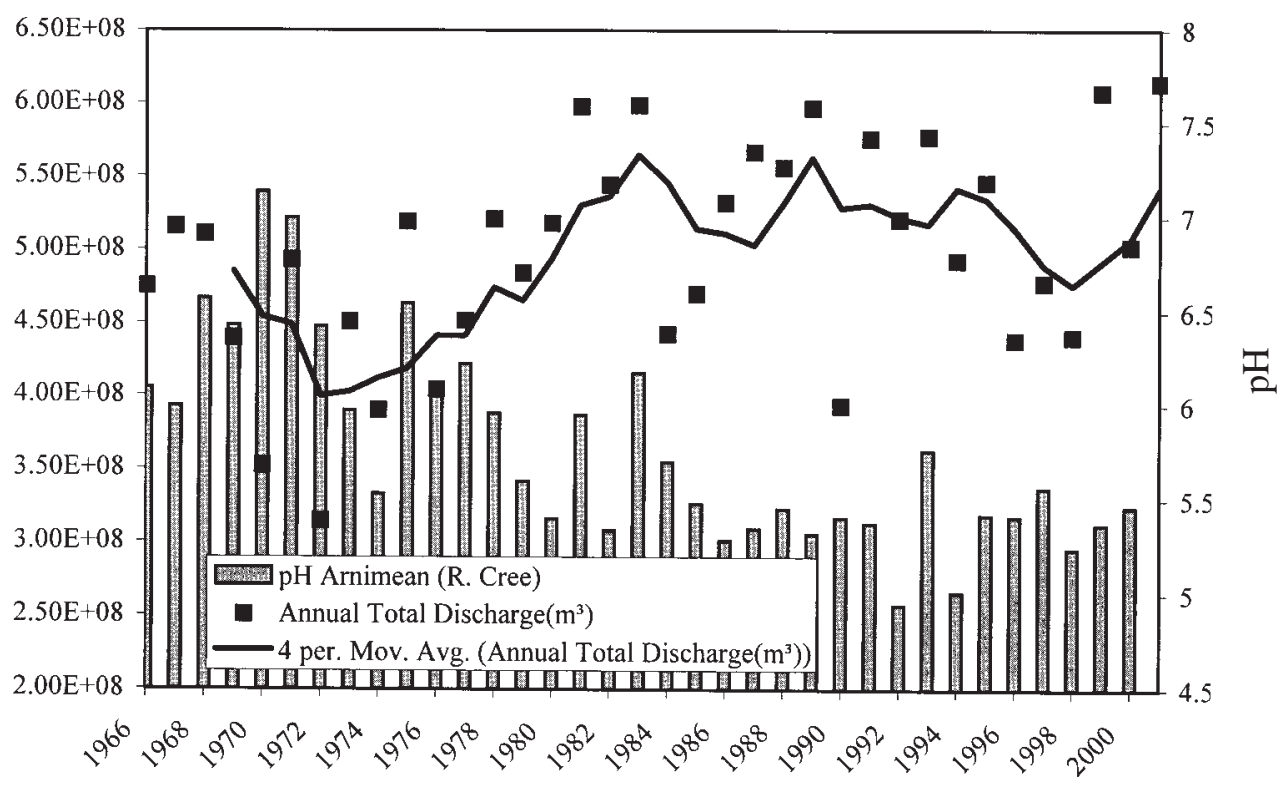

Fig. 5. Relationship between total annual flow and pH between 1966-2000

the Cree, it is apparent that $\mathrm{pH}$ increased significantly from 1956-1970 $\left(0.05 \mathrm{yr}^{-1}\right)$. A similar increase in $\mathrm{pH}$ was evident at Bladnoch (1964-1970), although the increase was not statistically significant $\left(0.07 \mathrm{yr}^{-1}\right)$. From the mid 1970s, evidence points to a decline in surface water $\mathrm{pH}$ for both the Cree and Bladnoch (Fig. 4). The total decline in $\mathrm{pH}$ measured at the Cree and Bladnoch from 1976-2000 was 0.76 and 0.64 , respectively. Statistical analysis of the entire dataset from the Cree (1956-2000) and Bladnoch (19642000) show the long term trend in $\mathrm{pH}$ is declining $\left(-0.02 \mathrm{yr}^{-1}\right.$ and $-0.03 \mathrm{yr}^{-1}$, respectively).

There is a strong relationship between $\mathrm{pH}$ and annual climatic variability. The relationship between river flow at Newton Stewart (downstream gauging station on the River Cree) and $\mathrm{pH}$ is presented in Fig. 5. Low annual total discharge records during 1969-1973 coincide with a period when $\mathrm{pH}>6$. Since 1973 total annual discharge has increased resulting in a gradual decline in surface water $\mathrm{pH}$.

\section{Discussion}

This analysis focuses on data supplied by SEPA whose databases provide the best record of long term change. These hydrochemical records are more extensive and the temporal resolution of these data is generally higher than most databases currently available in the UK. Although this data is useful for assessing long term trends in surface water chemistry, there are limitations that need to be taken into account when interpreting the results. These datasets include parameters that generally focus on potential pollutants which are related to discharge consents for industrial, agricultural and urban discharges. Consequently, there is a paucity of data relating to some of the main ionic species found naturally in river waters, especially the major weathering related cations. In addition to the limited range of parameters monitored, long-term analysis of trends is hindered by large gaps in the datasets at some sites, and limited information regarding analytical and quality procedures. Nonetheless, without these long term data, important historical changes in surface water acidity would not have been detected in the River Bladnoch at Shennanton and the River Cree at Arnimean.

In addition, small upland catchments were selected for monitoring primarily because the soils and waters draining these upland areas are generally more responsive to changes in atmospheric deposition and afforestation. In this regard, the higher drainage densities and steeper topography of this upland study area reduce the amount of time before runoff enters the stream network and consequently the time for potential soil buffering processes within the catchment.

This study demonstrates that surface water draining afforested catchments of the Cree and the Bladnoch are inherently more acid than those draining the moorland catchment of the Luce. Overall, the results corroborate findings from other studies conducted in this region (Puhr et al., 2000; Rees and Ribbons; 1995; Wright et al., 1994). The statistically significant decrease in surface water concentrations of $\mathrm{SO}_{4}^{*}$ and total $\mathrm{Al}$ in the upper reaches of the Rivers Cree and Bladnoch during 1984-1999 was insufficient to induce a recovery in $\mathrm{pH}$ at these afforested 
catchments. This indicates that extensive forestry in these catchments plays an important role in exacerbating deposition of acid pollutants such as S, through increased dry deposition (Fowler et al., 1989) and occult deposition (Dollard et al., 1983). These results suggest that in the heavily afforested sub-catchments, current reductions in S emissions do not lead to an observed improvement in the acid status of these rivers. Compared to the Cree and Bladnoch catchments, total S inputs at the Luce catchment, a predominantly moorland catchment, are small and as a consequence, the impact of $\mathrm{S}$ emission reductions on surface water quality are less apparent (Table 2). Nitrate concentrations in the River Luce are consistently lower than in the Rivers Cree and Bladnoch, a response to lower deposition inputs and the potential retention of $\mathrm{N}$ by the extensive area of peat in this catchment (Helliwell et al., 2001). As forests mature and uptake rates decline, greater $\mathrm{N}$ leaching to surface waters has been observed (Reynolds et al., 1994). In this study, however, the forest age in the Cree and Bladnoch sub-catchments is known to range from $30-50$ years old and yet there is no evidence of increasing $\mathrm{NO}_{3}$ concentrations in the surface waters.

In terms of assessing land use influences on surface water chemistry, the Luce catchment can be regarded as a control. Much of the catchment drains peat-covered hills and moorland overlying slow weathering Ordovician sediments and, as a consequence, the water draining these organic soils are naturally enriched in $\mathrm{H}$ and organically complexed Al.

Historical data from the mid 1950s to 1970 show an improvement in surface water $\mathrm{pH}$ in the River Cree at Arnimean. These findings contradict other studies that show an increase in surface water acidification in response to peak S emissions in the 1970s and large-scale commercial afforestation in the region (Wright et al., 1994; Puhr et al., 2000). Improvements in surface water $\mathrm{pH}$ during this time may be linked to the introduction of a UK subsidy on agricultural lime in the late 1930s. Although lime was not applied directly to forest soils, large areas of grassland/ moorland soils were limed during the 1940s to early 1960s. The application rate of lime used in agricultural production increased by as much as 14 times pre-war levels (BACMI, 1983). Whilst the area of forestry has expanded in this region during the 1970s and 1990s (Fig. 3) it is likely that a considerable part of this limed area is now afforested. Figure 4 shows an improvement in $\mathrm{pH}$ for the Cree and the Bladnoch when subsidised agricultural lime payments were at a maximum. In 1976, the subsidy on agricultural lime ceased (except were it is payable under other schemes such as the Farm or Horticulture Development schemes) and surface waters have progressively acidified. It is possible that this decline in $\mathrm{pH}$ may, in part, be a consequence of the reduction in lime application; however, the degree of recovery may be hindered by intensive forestry practices.

Lime additions to expansive areas of upland Britain were common practice in the first half of the $20^{\text {th }}$ century. In this regard, trend analysis on data from other upland areas in Britain, that are restricted to more recent data sets, should be interpreted with caution. In addition, these results raise important questions regarding the rate of acidification or recovery in systems that received no lime additions in the past. Even though the catchments described may have been limed in the past, recent analyses of hydrochemical data indicate that the rivers in Galloway remain acid.

It is also noteworthy that mean annual $\mathrm{pH}$ measurements were greatest during 1969-1973 when the total annual discharge was low. It is well documented that groundwater dominated low flows are characterised by high $\mathrm{pH}$ and alkalinity. Following 1973, pH gradually declined in response to higher rainfall and increased annual total discharge. Under these conditions, as flow increases, a mixing of soil drainage waters occurs which results in a reduction in $\mathrm{pH}$ and alkalinity (Jenkins et al., 1990b).

\section{Conclusions}

The first, and perhaps most significant, finding of this study is that surface water concentrations of $\mathrm{SO}_{4}^{*}$ have declined

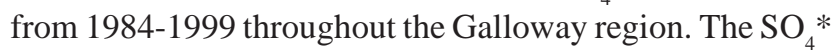
trend was highly significant in the Rivers Cree $(-1.34 \mu \mathrm{eq}$ $\left.\mathrm{l}^{-1} \mathrm{yr}^{-1}\right)$ and Bladnoch $\left(-2.32 \mu \mathrm{eq} \mathrm{l}^{-1} \mathrm{yr}^{-1}\right)$ but not statistically significant in the River Luce $\left(-0.016 \mu\right.$ eq $\left.1^{-1} \mathrm{yr}^{-1}\right)$. This decline in surface water $\mathrm{SO}_{4} *$ is consistent with reductions in $\mathrm{S}$ deposition.

Afforestation was found to have a deleterious impact on surface water chemistry. Compared to the River Luce (moorland catchment), that has a mean annual (1984-1999) surface water $\mathrm{pH}$ of 6.03 , the afforested catchments of the Rivers Cree and Bladnoch are more acid (pH 5.39 and 5.72, respectively).

Historical trends (1950-1970s) in surface water $\mathrm{pH}$ appear to be influenced by the large-scale application of lime to areas of rough grassland. Lime additions at this time were sufficient to offset surface water acidification as shown by the recovery in $\mathrm{pH}$ during this period (Fig. 4). Without lime addition in this region it is likely that the extensive afforestation and increasing levels of acid deposition at this time would have led to more acidic surface water conditions. This finding has important implications in terms of land preparation prior to future afforestation initiatives.

There is currently an increased awareness of the importance of long term datasets in assessing the response of surface water chemistry to environmental change. These 
analyses contribute to the understanding and detection of the impacts of changes in deposition and land use practices on freshwater ecosystems.

\section{Acknowledgements}

This project was financially supported by the Commission of the European Communities RECOVER:2010 project (EVK1-CT-1999-00018) and the Scottish Executive Environment and Rural Affairs Department (SEERAD). The authors are grateful to J. Potts from BioSS for advice on trend statistics. Thanks is also due to W. Halcrow (Director of Operations), G. Burns (Environmental Assessment Manager), B. Eriksen (Senior Hydrologist) and D.J. Pirie (Chemistry Services Manager) from the Scottish Environment Protection Agency.

The views expressed herein are those of the authors and do not necessarily reflect those of the Scottish Environment Protection Agency.

\section{References}

Alewell, C., Armbruster, M., Bittersohl, J., Evans, C.D., Meeseburg, H., Moritz, K. and Prechtel, A., 2001. Are there signs of acidification reversal in freshwaters of the low mountain ranges in Germany? Hydrol. Earth Syst. Sci., 5, 367-378.

BACMI, 1983. Lime in Agriculture. The Agricultural Lime Producers Council. Second Revised Edition, 12 pp.

Battarbee, R.W. and Charles, D.F., 1994. Lake acidification and the role of paleolimnology. In: Acidification of freshwater ecosystems: implications for the future, E.W. Steinberg and R.F. Wright (Eds.), 51-65. Wiley, Chichester, UK.

Daysh, G.H.J., 1974. Geology. In: Galloway Forest Park. Forestry Commission Guide, H.L. Edlin (Ed.), 24-27. Her Majesty's Stationery Office, Edinburgh.

Dollard G.J., Unsworth, M.H. and Harve, M.J., 1983. Pollutant transfer in upland regions by occult precipitation. Nature, 302, 241-243.

Edmunds, W.M. and Kinniburgh, D.G., 1986. The susceptibility of UK groundwaters to acidic deposition. J. Geol. Soc., 143, 707-720.

El-Shaarawi, A.H., Esterby, S.R. and Kuntz, K.W., 1983. A statistical evaluation of trends in water quality of the Niagara River. J. Great Lakes Res., 9, 234-240.

Evans, C.D. and Jenkins, A., 2000. Surface water acidification in the South Pennines. II. Temporal trends. Environ. Pollut., 109, 21-34.

Ferrier, R.C., Helliwell, R.C., Cosby, B.J., Jenkins, A. and Wright, R.F., 2001. Recovery from acidification of lochs in Galloway, south-west Scotland, UK: 1979-1998. Hydrol. Earth Syst. Sci., 5, 421-431.

Forestry Commission, 1999. Inventory report. National Inventory of Woodland and Trees. Scotland-Dumfries and Galloway region. Part 1 - Woodlands of two hectares and over. Woodlands Survey, Forest Research, 5-12.

Fowler, D., Cape, J.N., Leith, I.D., Choularton, T.W., Gay, M.J. and Jones, A., 1989. The influence of altitude on rainfall composition at Great Dun Fell. Atmos. Environ., 22, 1355-1362.
Harriman, R., Morrison, B.R.S., Birks, H.J.B., Christie, A.E.G., Collen, P. and Watt A.W. 1995. Long term chemical and biological trends in Scottish streams and lochs. Water Air Soil Pollut., 85, 701-706.

Harriman, R., Watt, A.W., Christie, A.E.G., Collen, P., Moore, D.W., McCartney, A.G., Taylor, E.M. and Watson, J., 2001. Interpretation of trends in acidic deposition and surface waters chemistry in Scotland during the past three decades. Hydrol. Earth Syst. Sci., 5, 407-420.

Helliwell, R.C., Ferrier, R.C. and Kernan, M.R., 2001. Interaction of nitrogen deposition and land use on soil and water quality in Scotland: issues of spatial variability and scale. Sci. Total Environ., 265, 51-63.

HMSO, 1980. Methods for the determination of Waters and Associated Materials. London.

Jenkins, A., Cosby, B.J., Ferrier, R.C., Walker, T.A.B. and Miller, J.D., 1990a. Modelling stream acidification in afforested catchments: an assessment of the relative effects of acid deposition and afforestation. J. Hydrol., 120, 163-181.

Jenkins, A., Harriman, R. and Tuck, S.J., 1990b. Integrated hydrochemical responses on the catchment scale. In: The Surface Water Acidification Programme, B.J. Mason (Ed.), 47-55. Cambridge University Press.

Jenkins, A., Helliwell, R.C., Swingewood, P.J., Sefton, C., Renshaw, M. and Ferrier, R.C., 1998. Will reduced sulphur emissions under the Second Sulphur Protocol lead to recovery of acid sensitive sites in UK? Environ. Pollut., 99, 309-318.

Lees, F.M., 1995. Have emission reductions led to improvements in water quality at Loch Dee in Galloway. Water Air Soil Pollut., 85, 695-700.

Miller, H.G., 1985. The possible role of forests in streamwater acidification. Soil Use Manage., 1, 28-29.

Puhr, C.B., Donoghue, D.N.M., Stephen, A.B., Tervet, D.J. and Sinclair, C., 2000. Regional patterns of stream water acidity and catchment afforestation in Galloway, SW Scotland. Water Air Soil Pollut., 120, 47-70.

Rees, R.M. and Ribbens, J.C.H., 1995. Relationships between afforestation, water chemistry and fish stocks in an upland catchment in south-west Scotland. Water Soil Air Pollut., 85, 303-308.

Reynolds, B., Ormerod, S.J. and Gee, A.S., 1994. Spatial patterns in stream nitrate concentrations in upland Wales in relation to catchment forest cover and forest age. Environ. Pollut., 84, 2733.

RGAR (Review Group on Acid Rain), 1997. Acid deposition in the United Kingdom 1992-1994. Fourth Report of the Review Group of Acid Rain. Report produced for the Department of the Environment, Transport and the Regions, AEA Technology Plc, 6 pp.

Soulsby, C., Turnbull, D., Langan, S.J., Owen, R. and Hirst, D., 1995. Long-term trends in stream water and biology in northeast Scotland: Evidence for recovery. Water Air Soil Pollut., 85, 689-694.

Tipping, E., Carrick, T.R., Hurley, M.A., James, J.B., Lawlor, A.J., Lofts, S., Rigg, E., Sutcliffe, D.W. and Woof, C., 1998. Reversal of acidification in upland waters of the lake district. Environ. Pollut., 103, 143-151.

Wright, R.F., Cosby, B.J., Ferrier, R.C., Jenkins, A., Bulger, A.J. and Harriman, R., 1994. Changes in acidification of lochs in Galloway, southwestern Scotland, 1979-1988: The MAGIC model used to evaluate the role of afforestation, calculate critical loads, and predict fish status. J. Hydrol., 161, 257-285. 